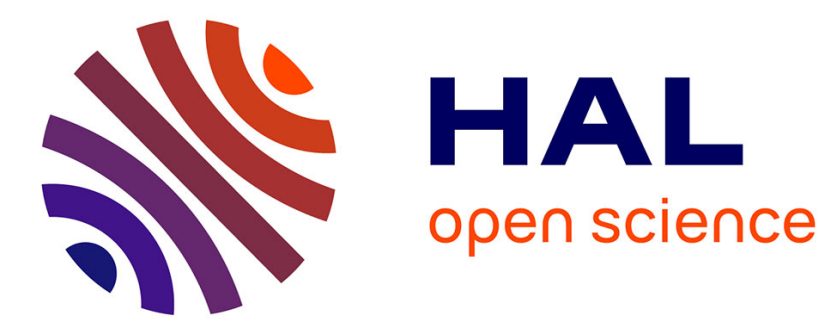

\title{
On Equity in India's Water Supply Public-Private Partnerships
}

Swann Bommier, Cécile Renouard

\section{To cite this version:}

Swann Bommier, Cécile Renouard. On Equity in India's Water Supply Public-Private Partnerships. 2014. hal-01023795

\section{HAL Id: hal-01023795 \\ https://essec.hal.science/hal-01023795}

Preprint submitted on 15 Jul 2014

HAL is a multi-disciplinary open access archive for the deposit and dissemination of scientific research documents, whether they are published or not. The documents may come from teaching and research institutions in France or abroad, or from public or private research centers.
L'archive ouverte pluridisciplinaire HAL, est destinée au dépôt et à la diffusion de documents scientifiques de niveau recherche, publiés ou non, émanant des établissements d'enseignement et de recherche français ou étrangers, des laboratoires publics ou privés. 


\title{
On ( quity in India's : ater 6 upply Public-Private Partnerships
}

\author{
Research Center \\ ESSEC Working Paper 1411
}

2014

Swann BOMMIER

Cécile RENOUARD 


\title{
On equity in India's water supply public-private partnerships
}

\author{
Swann Bommier \\ ( $\mathrm{PhD}$ candidate at CERI/Sciences Po, research assistant at ESSEC Business School) \\ and \\ Cécile Renouard \\ (ESSEC Business School)
}

\begin{abstract}
This article studies the implementation of a public-private partnership (PPP) in the water supply sector in Nagpur (Maharashtra, India). Drawing upon the capability approach and the concept of disadvantage, we define equity as the need to focus on the worse-off. Based on extensive fieldresearch, we explain how the access to water is currently characterized by patronage relations and institutional discriminatory practices that perpetuate categorical inequalities. Addressing equity concerns in a PPP therefore requires questioning the existing power relations to clearly prioritize the worse-off. Our research argues that international law might be used to promote equitable processes in urban infrastructure, beyond today's focus on technical accounts and efficiency debates.
\end{abstract}

\section{Keywords}

India, equity, disadvantage, public-private partnership, categorical inequalities, JNNURM 


\section{INTRODUCTION}

Inequalities in access to public services in the Indian cities are a major development challenge (Zerah, 2008). Patrick Heller and Peter Evans distinguish three competing views on the origins of social inequalities (Heller \& Evans, 2010). First of all, the "residualist" view, influential among policy-makers and international donors, considers that inequalities are caused by market failures, bad public policies, and could thus be resolved by a focus on 'good governance', public accountability and managerial efficiency (WB, 2004). This view is however criticized for depoliticizing and adopting a techno-managerial approach to development programmes that does not allow to counter the root causes of poverty and inequalities (Harriss, 2002; Leftwich, 1993, 2005). Secondly, the "structuralist" view considers that inequalities are created by the neoliberal capitalist model (Korten, 1995). This approach calls for a global reform of the neo-liberal political economy, but is "ill-adapted to explaining variations in trajectories of political change among countries [and underestimates the] local variations in democratization and citizenship [...] to combating the brutal inequalities of the Southern Metropolis" (Heller \& Evans, 2010, p. 437). Recent studies have thus moved beyond the "residualist" or the "structuralist" typologies, and have analyzed how marginalized communities are empowered by social movements, and how former "citizens without a city" (Appadurai, 2002) gain access to public services. Charles Tilly's "categorical" approach to inequalities provides a new framework of analysis in this direction (Mosse, 2010). Drawing upon Weber's analysis of "social closure" (Weber, 1968), Charles Tilly has studied the protracted nature of social inequalities. These inequalities, he argues, are not based on individual behaviors or a lack of "social capital" (Harriss, 2002), but rather on social structures that function in binary terms and perpetuate exclusions. "Collective experience and social interactions" (Tilly, 1998, p. 24) then lock these categorically unequal structures in place.

International organizations have publicly acknowledged the categorical character of inequalities in development and in water supply. In this framework, countering inequalities has led to the focus of policy-makers and international organizations towards equity concerns (UNDP, 2006, 2011; WB, 2006). Thus, politics is supposed to strive to lead to equitable development (Hickey, 2008). Yet, one wonders how the acknowledged frameworks of categorical inequalities and equity are embedded in today's development projects. 
How do the actors involved in urban development projects confront the social and political processes which maintain categorical inequalities in place? Which dynamics perpetuate the status quo and hinder the promotion of equity? Drawing upon a six-months field research in the 2.5 million-inhabitants city of Nagpur (Maharashtra, India), the present article studies the launch of a city-wide public-private partnership (PPP) in the water supply sector under the Jawaharlal Nehru National Urban Renewal Mission (JNNURM), a US\$ 12 billion program for urban infrastructure development partially funded by the World Bank (D. Kundu \& Samanta, 2011; Prime Minister, 2005). Our thesis is that, while categorical inequalities and politics play a major role in the perpetuation of inequalities in access to water, actors do not have officially proclaimed operational criteria and guidelines allowing them to legitimately contest the status quo and tackle inequalities based on their categorical root causes. This results in the further exclusion of the currently marginalized communities.

First (section 2), the article draws on the evolution of the development discourse over the last decade towards an equity agenda (UNDP, 2011; WB, 2006). We show that this discourse is convergent with some equity theories (Rawls, 1971; Sen, 1999) and we stress its implications in terms of public policies (Nussbaum, 2000a; Wolff \& De-Shalit, 2007): the need to identify clusters of disadvantages and focus on the least advantaged. The Nagpur case study and the unequal access to water in its 446 slums is then described in detail (section 3) to show how legal hurdles, administrative barriers, political clientelism and patronage-like relations characterize the Indian social and political environment as a 'mediated state' (Berenschot, 2010, p. 885), confirming the existence of categorical inequalities. In this 'mediated state,' we are able to identify a 'least advantaged' population categorically marginalized: the non-notified slums. Finally (section 4), we scrutinize the discourse that presents the introduction of private players in the provision of public services as a win-win situation to simultaneously address the inefficiencies of public utilities and the equity requirements in developing countries (MoF, 2009; MoWR, 2012; UNGA, 2006; WB, 2006). Interviews with government officials, private actors involved in the PPP and political leaders suggest that the JNNURM and PPP reform remains embedded in a residualist approach that is not likely to enhance the capabilities of the least advantaged. We contend that moving from an implementation of development projects based on residualist concerns towards a categorical approach that contests the existing status quo requires to define operational criteria and guidelines based on the concept of equity stemming from the 
capability approach and Wolff and de-Shalit's concept of disadvantage. We study how international law might legitimize and facilitate this transition towards effective equitable development.

\section{DEVELOPMENT, EQUITY AND THE HUMAN RIGHT TO WATER}

Drinking water supply has been a major focus of the international community's development efforts. In September 2000, the tenth target of the Millennium Development Goals listed 'sustainable access to safe drinking water and basic sanitation' as a challenge towards environmental sustainability and ending poverty (UN, 2006, no. 7). In 2002, the UN Committee on Economic, Social and Cultural Rights, commenting on articles 11 and 12 of the International Covenant on Economic, Social and Cultural Rights ${ }^{1}$ recognized that 'States parties have to adopt effective measures to realize, without discrimination, the right to water' (UN ECOSOC, 2003). Following recurring declarations by international bodies ${ }^{2}$ insisting on the importance of water in an individuals' life, the UN General Assembly recognized on July 28, 2010 the 'human right to water and sanitation, [...] acknowledging the importance of equitable access to safe and clean drinking water as an integral component of the realization of all human rights' (UNGA, 2010).

While new figures showed a decline in in-house connections from 51 per cent of urban households in 2006 to 48 per cent in 2008 (M. Mehta \& Mehta, 2010, p. 22; WHO \& UNICEF, 2010), the Indian government voted in favor of this resolution and committed itself in the international arena towards equitable and universal access to drinking water.

This commitment raises different issues concerning the definition of equity and the way to achieve this goal. In its 2006 World Development Report on 'Equity and development', equity has been defined by the World Bank 'in terms of two basic principles. The first is equal opportunities [...] the second principle is the avoidance of deprivation in outcomes, particularly in health, education and consumption levels' (WB, 2006, p. xi). The World Bank's president,

\footnotetext{
${ }^{1}$ Article 1 deals with the 'right of everyone to an adequate standard of living for himself and his family', article 12 with the 'right of everyone to the enjoyment of the highest attainable standard of physical and mental health' (UNGA, 1966)

${ }^{2}$ e.g. WHO - UNICEF Joint Monitoring Programme for Water Supply and Sanitation, UN World Water Assessment Programme
} 
Paul Wolfowitz, has acknowledged the subsequent duty of public policies to focus on the worseoff:

Public action should seek to expand the opportunity sets of those who, in the absence of policy interventions, have the least resources, voice and capabilities. (WB, 2006, p. xi)

This perspective is close to Rawls' approach of justice (Rawls 1971). Indeed, the equity criteria defined by Rawls is threefold: first, each person is entitled to equal basic rights and opportunities; second, equality of opportunity is defended; third, the priority has to be given to the worse-off. Moreover,

the first principle covering the equal basic rights and liberties may easily be preceded by a lexically prior principle stating that citizen's basic needs be met, at least insofar as their being met is necessary for citizens to understand and to be able to fruitfully exercise those rights and liberties (Rawls, 1993, p. 7).

Rawls thereby justifies the need to focus on the improvement of access to 'primary goods' by maximizing the share of the worse-off for each of these identified primary goods. This 'maximin' principle (Rawls, 1971, 1993) guarantees a minimal threshold for diverse basic human needs.

However, by focusing on means and outcomes, such as consumption levels or primary goods, Rawls' and the World Bank's approaches need to be complemented to 'concentrate on what actual opportunities a person has, not the means over which she has command' (Sen, 2004, p. 332). Based on this idea of 'actual opportunities,' a new approach to development appeared in the 1990s with the publication of the Human Development Index (Jenkins, 2005, p. 529; Rist, 2008; UNDP, 1990, 2011; WB, 2006), which was designed to assess a person's quality of life.

Measures of utility or material wealth fail to make explicit the actual well-being of an individual and their actual quality of life (Sen \& Nussbaum, 1993; Stiglitz, Sen, \& Fitoussi, 2010; UNDP, 1990). Acknowledging the failures of monist theories, ${ }^{3}$ the capability approach and its focus on choice and opportunities allows one to better assess a person's well-being. Indeed, while the definition of a list of 'primary goods' retains a basis for a multidimensional approach, it is not

\footnotetext{
${ }^{3}$ A theory where 'all advantages and disadvantages can be reduced to a single good or source' (Wolff \& De-Shalit, 2007, p. 22)
} 
able to account for complex trade-offs and interactions across spheres of existence of different natures (Walzer, 1983; Wolff \& De-Shalit, 2007, pp. 22-34).

Through the concept of 'alternative combinations', the capability approach identifies the 'genuine opportunities' a person has at their disposal (Wolff \& De-Shalit, 2007, p. 80), and analyzes how the person chooses among their existing functionings ${ }^{4}$. It is therefore necessary to define some basic entitlements, or 'central capabilities,' that one should not be forced to trade off (Nussbaum, 2000a, p. 1025). Indeed, when a person is confronted with a trade-off that threatens to jeopardize one essential functioning to secure another one, they face a tragic situation of 'inverse cross-category risk' (Wolff \& De-Shalit, 2007, p. 70). In contexts where a wide range of human rights are not guaranteed, the concept of 'inverse cross-category risk' illustrates the rational decision-making processes people living in a fragile situation are forced into (Bracking, 2005 , p. 1014). This allows us to emphasize the importance of the structural conditions of choice, where a lack of reasonable alternatives demonstrates the perpetuation of 'power and dominance [both] through consent and complicity as well as through coercion and conflict' (Kabeer, 1999, pp. 441-3). In this political framework of power and dominance, a disadvantaged person can be defined as one who is not able to sustain their basic human rights and capabilities:

One central way of being disadvantaged is when one's functionings are or become insecure involuntarily, or when, in order to secure certain functionings, one is forced to make other functionings insecure, in a way that other people do not have to do. (Wolff \& De-Shalit, 2007, p. 72)

The maximin principle within John Rawls' theory requires public policies to favor the worse-off regarding some 'primary goods'. By using the multidimensional approach of capabilities and using the concept of 'inverse cross-category risk,' we see that the worse-off in a given society are those who live in clusters of disadvantage, where 'patterns of disadvantage form and persist' (Wolff \& De-Shalit, 2007, p. 121). In order to respond to the maximin equity principle, public policies are thus asked to de-cluster disadvantage.

\footnotetext{
${ }^{4}$ Functioning can be defined as the 'doing or being' a person realizes (Sen \& Dreze, 2002, p. 35); capability accounts for people's capacity to choose between 'alternative combinations of functionings' (Sen \& Dreze, 2002, p. 35; Sen, 2004, p. 332) in leading a life they value or have reasons to value (Sen, 1999).
} 


\section{IDENTIFYING THE DRIVERS FOR DISADVANTAGE AND THE LEAST ADVANTAGED}

Studies have shown that clusters of disadvantage are either the result of processes (traditional rules, legal and administrative regulations, norms and practices) that undermine people's agency ${ }^{5}$ in 'strategic life choices' (Kabeer, 1999, pp. 456-61), or the result of causal relations (Krishna, 2013). Our case study of the city of Nagpur looks at the cluster of disadvantage that arises from living in informal settlements. Studying this cluster allows us to identify Nagpur's least advantaged population.

\section{Nagpur: presentation and description of slums challenge}

The Nagpur Municipal Corporation (NMC) is the thirteenth largest Indian municipality, and has, as per the Census of 2011, a population of 2.5 million inhabitants that has grown at a high (albeit decreasing) rate (+24.74 per cent from 1991 to $2001,+14.39$ per cent from 2001 to 2011).

Nagpur's water supply infrastructure was historically secured through wells and three lakes located around the fortified city. The British built an artificial lake in 1911, as well as reservoirs, a water treatment plant and a water supply network to ensure a continuous water supply through gravity in the colonial neighborhood (NMC, 2012). The historical city center was neglected, as in other Indian cities (Mann, 2007). The north-western part of the city and the former colonial neighborhood thus receive better water supply than the eastern and southern parts of the city, which lay at the end of the water supply network. At the city level, there are thus technical and historical colonial roots in the geographical disparity of water supply (Bakker, Kooy, Shofiani, \& Martijn, 2008).

On a smaller scale, however, poor access to public services relates to housing status: 36 per cent of Nagpur's population (i.e. approximately 858,000 persons) live in 446 listed slums spread across the city, where the population has limited access to basic services and constitutes the poorest section of the municipality's inhabitants (Dravekar, 2011). Slums are defined based on the criteria of the Maharashtra Slum Areas Act of 1971. According to this State jurisdiction, a slum is an area in which buildings are 'unfit for human habitation,' or where public infrastructures do not meet minimal standards and are thus considered 'not reasonably suitable

\footnotetext{
${ }^{5}$ Defined as the 'decision-making' process (Kabeer, 1999, p. 445)
} 
for occupation in that condition' (GoM, 1971, sec. 4.A. Declaration of Slum Areas). Although access to basic facilities is generally characterized as poorer in slums as compared to formal settlements, a comparative analysis across slums reveals high levels of heterogeneity in access to public services and water supply (NMC, CHF, \& ESAF, 2008): while the vast majority of slums benefits from a quite developed water network, others are totally left out. Water services therefore correspond to what Bakker et al. describe as an 'archipelago', rather than a continuous network (Bakker et al., 2008, p. 1899).

In the following, we will describe the processes through which the slum's administrative and political statuses shape its access to public services and inclusion in development projects. This will allow us to identify the root causes of urban inequalities as relational categorical inequalities, to borrow from Tilly's terminology.

\section{Equity challenges in light of financing and administrative debates: notification}

While 'slums' are officially defined as per the availability of basic amenities and infrastructures, an administrative procedure set out in the Maharashtra Slum Areas Act called 'notification process' institutionalizes a binary category among slums and opens access to specific development funds and authorizations.

The notification process consists of a survey relating to 'size of area, number of huts, total number of structures, [and] population' (Interview with local administration employee, August 2011). A set of non-listed criteria embedded in the administrative practices are also taken into account, including: age of the slum, ownership of the land where the slum is located, ${ }^{6}$ and landuse definition as per the City Development Plan. ${ }^{7}$ Notification therefore depends on technical criteria, administrative rules and political considerations.

Out of the 446 slums the city accounts for, 159 are thus categorized as non-notified slums (NMC et al., 2008). They house a total of approximately 150,000 persons (about 6.5 per cent of Nagpur's population, or 20 per cent of the slums' population) (MMC Consultants, 2005).

\footnotetext{
${ }^{6}$ Private ownership, public ownership under the jurisdiction of the municipality, State or Central Government

${ }^{7}$ Residential, commercial, institutional land-use
} 
Until 2002, slums were developed exclusively based on 'perceived development needs' (Interview with local administration's employee, August 2011). Depending on the requirements and proposals of local representatives, funds were allocated for development and maintenance works. Infrastructure development in slums was conducted on a discretionary basis, and motivated by clientelist strategies, without legally binding procedures and audits concerned with relevance of works and equal distribution of funds across the city. The notification status did not matter (Interview with head of a local NGO active in capacity-building with the municipality's Slum Department, September 2011).

In 2002, however, the German development agency GTZ implemented a capacity-building mission with the NMC to list and survey all slums and come up with an official 'slums masterlist' that would differentiate notified and non-notified slums. Legally speaking, 'the object of declaring any area as [a notified slum] is to take care of sanitation and provide all basic facilities' (GoM, 1971, sec. 3.C. Declaration of a slum rehabilitation area). Within the NMC's budget, five per cent (270 million rupees, i.e. 4.22 million Euros in 2012) are allocated to development works performed in notified slums. These funds are managed by the Weaker Section Department (WSD). While notification had no impact on the allocation of funds up to 2002, procedures became more stringent with the publication of the master list. The WSD started to allocate funds exclusively to the notified slums, but maintenance and basic works were still permitted in nonnotified slums on the regular municipal budget.

In 2006, the Slum Rehabilitation Authority (SRA) was created in Nagpur as per the Maharashtra Slum Areas Act. Its mission is to efficiently manage all funds dedicated to slums. The SRA became the competent authority to manage all public funds channeled through the municipal administration (whether WSD, municipal, federal or national funds) to develop 'slum-free cities ${ }^{8}$. As non-notified slums were not meeting the current rules and regulations regarding the town planning and ownership requirements, the SRA unilaterally decided to stop the incremental development of all non-notified slums and relocate its population to newly developed urban areas. As a consequence, since 2006, development and maintenance of all public infrastructure, including basic improvements to respond to urgent needs in water supply, have been stopped

\footnotetext{
${ }^{8}$ The BSUP (Basic Services to Urban Poor), the pro-poor wing of the JNNURM, and the newly funded program RAY (Rajiv Awas Yojana) are both meant to develop 'slum-free cities'.
} 
(Interview with an employee of the SRA, October 2011; Assistant Commissioner November 2011).

Over the last decade, administrative practices perpetuated and even reinforced the existing inequalities and disadvantages of non-notified slums as compared to notified slums and formal neighborhoods. Emulation, defined as "the copying of established organizational models and / or the transplanting of existing social relations from one setting to another” (Tilly, 1998, p. 10), took place, and the administrative categories of the WSD were generalized by the SRA to the management of all public schemes. As we will see, these administrative discriminatory practices resulted in a higher political disadvantage, and reinforced the political "inverse cross-category risk" among the non-notified population.

\section{Clientelism and patronage}

The Indian slum population votes in higher numbers to gain political visibility (Berenschot, 2010, p. 888; Chandra, 2004). In a fund-constrained environment, as 'political leaders know more about the locality and its requirements' (Interview with Assistant Commissioner, October 2011, November 2011), maintenance and development of public infrastructure are enforced through the constant pressure municipal elected representatives put on the administration (Interview with locally elected representatives, 2011). The areas whose elected representatives are the most influential are thus privileged.

Evidence collected in Nagpur highlights the wide array of clientelist strategies through which elected representatives trade votes for access to public resources and services (Bénit-Gbaffou, 2011, p. 433; Keefer \& Khemani, 2004; Kitschelt \& Wilkinson, 2007; Kohli, 1990). Elected representatives thus operate a 'political mediation' (Berenschot, 2010) between non-notified slums and access to public services (Jha, Rao, \& Woolcock, 2005, pp. 13, 21)

All elected representatives have 'personal funds' granted by the government on a yearly basis to finance their own projects in their constituencies. ${ }^{9}$ At the State and national level, the Members of the State Legislative Assembly (MLAs), the Members of the Lower Chamber (MLCs) and the Members of Parliament (MPs) dispose altogether of large amounts of funds that contribute to

\footnotetext{
${ }^{9}$ In Nagpur, a Corporator receives 1.5 million rupees (23,400 Euro) per year, in Maharashtra an MLA receives 20 million rupees $(312,500$ Euro) per year
} 
infrastructure development and maintenance works in slums (be it notified or non-notified slums). At the municipal level, the funds of the elected representatives (Corporators) are closely monitored by the SRA. However, the Corporators use political bargaining practices to channel funds received by MLAs, MLCs or MPs (which the SRA does not control, as it is not channeled through the municipal administration) to non-notified slums. Kick-back commissions received when granting development projects in notified slums or formal neighborhoods also allow them to informally reinvest in non-notified slums.

Political bargaining, informal practices undertaken by Corporators and the lack of sovereignty of the NMC in the way MLAs, MLCs and MPs allocate the funds they obtain from their administrative counterparts all contribute to the development of personal strategies for the accumulation of power that have no link with objective needs and equity concerns (i.e. a focus on the least advantaged). Thus, slums have secured access to water through various formal or informal processes (Zerah, 2000) which elected representatives have funded or protected from administrative control and disruption.

While administrative rules were tightened over the last decade, the governance of public services became "less a matter of politics and more of administrative policy, a business for experts rather than for political representatives" (Chatterjee, 2004, p. 35). From the administrative perspective, the perspective of developing 'slum-free cities' and evicting non-notified slums denied the legitimacy of the people's claims for in-situ development (Interview with a local elected representative, November 2011). The non-notified slums therefore came to depend completely upon the discretionary power of their elected representatives to gain access to minimal levels of public services and protection from eviction. The existing patron-client relation was thereby reinforced. As Chatterjee notes, for those people living in informal settlements, the "inverse cross-category risk" of auctioning votes for protection is a key element towards the development of 'vote banks' (Chandra, 2004):

"This would frequently mean the bending or stretching of rules, because existing procedures have historically worked to exclude or marginalize them. They must, therefore, succeed in mobilizing population groups to produce a local political consensus that can effectively work against the distribution of power in society as a whole" (Chatterjee, 2004, p. 66) 
Another example highlights the discrepancy between the administrative rules and the electoral strategies of elected representatives. The administration indeed regularly performs "regularization drives" in formal neighborhoods and notified slums to increase the water supply billing efficiency and to embed existing illegal water connections in the formal sector. The regularization drive conducted in Nagpur in 2001 was documented as a 'best practice' by Indian government institutions (ASCI \& Centre for Good Governance, 2011; Pangotra \& Hastak, 2004). The non-notified slums are however excluded from the process. The administration indeed considers that such regularizations would grant non-notified slums official access to public services, and in turn undermine the administration's eviction policy (Albuquerque \& Roaf, 2012).

Due to this conflict between the eviction strategy of the SRA and the 'vote-bank' strategies of elected representatives who want to nurture and secure a large pool of loyal clients, non-notified slums remain in a protracted status-quo where their situation does not improve, and is unlikely to change. As Chatterjee notes, the non-notified slums are drawn into a "political society", defined as a society which seeks protection and access to public services through political bargaining and popular mobilization rather than through legal and well-entrenched processes (Chatterjee, 2004, p. 47).

Non-notified slums' inhabitants are thus drawn in an 'inverse cross-category risk' logic, where their access to water is secured through informal processes that undermine their political autonomy. The patron-client relation that links elected representatives to the non-notified population through a 'vote for services' impedes the population from requesting to their elected representatives to propose global regulatory reforms that will undermine their position as patrons (Bénit-Gbaffou, 2011, p. 461). Elected representatives thus remain mediators in the service provision and do not play a role of 'policy-making'. The population of the non-notified slums thus lives, beyond the administrative discrimination, in a protracted state of political disadvantage that no one else experiences in the city.

\section{Non-notified slums as the least advantaged}

The population living in non-notified slums is thus caught in a trap of exclusion, administratively speaking, and patronage, politically speaking. These two processes feed each other and create a 
cluster of 'corrosive disadvantages,' which are defined as 'something whose absence or insecurity will lead to problems with other functionings' (Wolff \& De-Shalit, 2007, p. 138). These corrosive disadvantages, which no-one else experiences in Nagpur, create a cluster of disadvantage which affects a wide range of capabilities: 'control over one's life and environment', 'health and water', 'affiliation' and 'emotional stability' (Nussbaum, 2000b). We can thus identify the least-advantaged population of Nagpur as the 150,000 persons living in non-notified slums.

Based on the definition of equity as focusing on the least advantaged, public policies should focus on the development of non-notified slums. Having identified a strong cluster of disadvantage, we see that standard calls for accountability between the population and the water service provider (be it a public or private entity) cannot solve this stalemate unless the nature of the settlement (formal or informal, notified or non-notified) is considered independently from the conditions of access to public services. As we will see, looking at the early stages of the implementation of the PPP project in Nagpur, this questions the capacity of international donors and of the Indian government to shift from a residualist to a political approach in development projects.

\section{POLITICIZING URBAN INFRASTRUCTURE REFORMS BEYOND THE RECURRENT CALL FOR PPPS}

In 2007, the World Bank funded a pilot project in a neighborhood of Nagpur for uninterrupted water supply (Judge Ahluwalia \& Nair, 2010). This project was taken up under the PPP model by Veolia, a French MNC and international leader in water management services. In November 2011, this pilot project was extended to the full city under a 25-year PPP contract in the frame of the JNNURM (Hitavada, 2011). The Nagpur Municipal Corporation (NMC) thus became the first Indian city to fully hand over the operations and maintenance (O\&M) of its water supply system to a private operator, Orange City Water $(\mathrm{OCW})^{10}$.

International organizations such as the $\mathrm{UN}$, the World Bank and the Indian government have promoted PPPs to address challenges of urban water supply, and invoked their shared concern for equity in advocating this reform. Multinational corporations (MNCs) have equally stepped

\footnotetext{
${ }^{10}$ A 50/50 joint venture between Veolia and the local construction company VIL
} 
into the equity discourse and publicly voiced their ambition to favor human development and equity, being responsible 'corporate citizens' (Moon, Crane, \& Matten, 2005; Scherer \& Palazzo, 2007; Sethi, 2008). The political nature of water supply has been repeatedly documented in the literature (Bakker et al., 2008; Connors, 2005; Swyngedouw, 2004, pp. 30, 36; UNDP, 2006). However, we do not engage here in the widely debated question on the impact of privatization on stakeholders, on financial sustainability or on affordability of privatized services (Estache \& Griffel-Tatjé, 2013; Hailu, Guerreiro Osorio, \& Tsukada, 2012; Tan, 2012). As Bakker et al. indeed note,

"the debate over the relative merits of public and private sector provision has diverted attention from the pressing issue of governance reform necessary to meet water-related development goals" (Bakker et al., 2008, p. 1907).

Taking Nagpur's JNNURM reform and existing pilot project as field evidence, we rather examine how Nagpur's governance reform, which sets an important milestone in India's water supply sector and urban infrastructure development reform, has been able to deal with the political and regulatory reforms required to tackle the cluster of disadvantage identified above. Water supply is therefore used as a proxy to reveal political challenges related to equity in the southern metropolis.

\section{Failing to operationalize equity in the pilot project of the World Bank}

In the pilot project funded by the World Bank and launched in a Nagpur's neighborhood in 2007 , the water supply O\&M managed under a PPP by Veolia maintained the discrimination between notified and non-notified slums: in notified slums, universal access was ensured through subsidized individual water supply connections. In non-notified slums, no works were undertaken, and the population relied exclusively on the illegal network it had self-financed and illegally connected to the municipal network, without technical or financial assistance for the network's maintenance (Interview with slum inhabitants of the pilot project neighborhood, 2011). The main issue highlighted by the informal slum leader of a non-notified slum built in 1985 on a private land was the fear of being disconnected, as works on water networks were being conducted in the frame of the pilot project in the surrounding area. In the meantime, the private operator, with the approval of the Water Works Department, which was regulating this 
small-scale PPP, disconnected 122 out of the 129 public taps that had been installed in that neighborhood to increase billing efficiency (Roy, 2011b). The perpetuating administrative discrimination coupled with the disconnection of public taps connected to the municipal water network thus created a completely privatized system of access to water. As non-notified slums did not benefit from subsidies and permission to apply for legal connections, their access to treated water was automatically put at greater risk. Due to the uncertainty regarding the possible disconnection of their illegal network from the municipal network, the population was asking, in vain, for support from its elected representative to regularize their illegal connections (Interview with informal slum leader, August 2011).

This case study reveals that the pilot PPP project financed by the World Bank in Nagpur reinforced the existing cluster of disadvantage by adding to the existing uncertainty of future access to water. Managers of Veolia in charge of this pilot project explained that no funds and no authorizations were granted by the administration to conduct works in these non-notified slums. In 2011, four years after the project launch, the private service provider had had no impact on reforming the existing categorical inequalities. The introduction of a small-scale PPP had not modified the situation of the least advantaged (Bakker et al., 2008, p. 1906; Gerlach \& Franceys, 2010, p. 1232).

The pilot project illustrates the limits of PPPs to address structural inequalities and discriminatory practices (UNDP, 2006). As we will see, the urban infrastructure governance reforms proposed by the World Bank and the Indian government under the PPP model remains entangled in a residualist approach.

\section{Full-city PPP: perpetuating a techno-managerial approach}

The 'Public Private Partnership in Infrastructure' (PPPI) Program of the World Bank details its mandate as promoting PPPs for their increased economic and financial efficiency. ${ }^{11}$ It does not include a capacity-building component related to regulatory frameworks to account for the equity challenges. Promotion of PPPs therefore still focuses on 'consensual techno-managerial management' (Swyngedouw, 2013, p. 832), in which the power relations within the

${ }^{11}$ Efficiency is indeed defined as 'Value for Money', i.e. 'the better quality of services for the same amount spent by the public sector [...] to accelerate [within imposed budgetary constraints] delivery of projects which might otherwise have to be delayed' (WB, 2011) 
administration and the political pressures to maintain a system of patronage and a parallel system of 'informal providers' are silenced. Possible tensions between political, economic and administrative actors on matters of sovereignty in allocating budgets and implementing reforms regarding equity criteria are not addressed by the World Bank’s program.

At the inception of the city-scale PPP, the memorandum of understanding (MoU) signed between the NMC and the Veolia-VIL joint venture did not specifically address the situation in nonnotified slums; nor did it mention necessary negotiations with other municipal departments, such as the SRA, to reach an equitable solution. The current stalemate on equity issues regarding nonnotified slums 'seems to have been ignored [in the JNNURM]' (D. Kundu \& Samanta, 2011, p. 57), and the two indicators assessing the performance of the private operator were related to nonrevenue for water and billing efficiency. Technical processes regarding human resources, financial set-up, accounting and auditing regarding investment targets were also detailed extensively (NMC, Nagpur Environmental Services Limited, \& OCW, 2011). The JNNURM reform thus referred exclusively to the 'often over-emphasized' technical and financial efficiency criteria (Albuquerque \& Roaf, 2012, p. 123).

Interviews with administrative officials revealed the silo vision and procedures in the administration, as no official dialogue had been initiated between the Water Works Department, the SRA, the municipal mayor and head of the administration. The status quo regarding existing rules and regulations within the administration were likely to be maintained, as funds for nonnotified slums had not been granted in the initial financial set-up of the PPP (Personal communication, Water Works Department employee, 2011). No needs-based criteria or formal regulations were defined to guarantee that JNNURM funds and public funds attributed to alternative modes of supply ${ }^{12}$ would respond to objective equity criteria rather than electoral considerations.

Considering the increased privatized system of access to water in the pilot project, one would expect that tanker supply would respond to the equity criteria and guarantee water supply in nonnotified slums. However, no mention was made to the management of alternative sources of

\footnotetext{
${ }^{12}$ Either through the set-up of public taps or management of tankers by elected representatives.
} 
treated water in the PPP contract. The unregulated and informal process of decision-making between the demands of the Corporators and the Water Works Department officials in charge of allocating tankers to specific areas thereby reinforces the position of elected representatives as patrons

The aim of the PPP is universal access to water (Roy, 2011a). The neglect shown towards nonnotified slums in official documents however undermines their capacity to be included in the public debate. On the one hand, the official performance targets defined in the PPP contract do not mention the existence of 'non-notified slums', nor their legal and administrative specificity. On the other hand this discrimination was politically legitimized, the second prize of the 'National Urban Water Awards' provided by the central government's Ministry of Urban Development being awarded to the NMC for its PPP initiative in the pilot project on August 13, 2009, regardless of the on-going discrimination suffered by the non-notified slums in the pilot area (Judge Ahluwalia \& Nair, 2010).

The lack of normative frameworks at the municipal level enabling funds to be channeled to the worst-off areas and least-advantaged (i.e. non-notified) population was seen by a former MLA as: (1) a failure by the PPP to effectively change existing unequal access to public services; and (2) a cynical stand of the JNNURM with respect to the existing political challenges of discrimination and patronage (Interview with an MLA, December 2011).

The JNNURM regulatory reform is thus a partial technical and managerial shift with no link to the actual challenges of equitable distribution of water resources. It does indeed not question water supply issues as a whole in the 'diverse array of water provision systems actually operating in [the] urban environment' (Bakker et al., 2008, p. 1908).

\section{Are the World Bank and the Indian government perpetuating the residualist view?}

Analyzing the World Bank's discourse is relevant to understand how its internationally acknowledged focus towards equity fails to be converted in operational terms. The World Bank indeed negotiated with the Indian government a loan dedicated to strengthening the JNNURM by increasing the amount of funds at the disposal of the target cities to develop urban infrastructure (The Economic Times, 2009). The World Bank also remains the largest fund provider for infrastructure development in the water sector, with an estimated 72 percent of the total amount 
of foreign funds brought to the sector (Briscoe \& Malik, 2006, p. 74). Looking at the way this organization prioritizes efficiency compared to equity highlights existing hurdles and the mainstream development practices which the Indian government has taken up.

In its above-mentioned 2006 report on equity and development, the World Bank had defined equity in Rawlsian terms, and its president, Paul Wolfowitz, had legitimized the focus on the least advantaged. However the report tries to reconcile the equity and economic efficiency paradigm by stating that:

"The dichotomy between policies for growth and policies specifically aimed at equity is false. The distribution of opportunities and the growth process are jointly determined" (WB, 2006, p. 10)

From the World Bank's perspective, the challenge of equity becomes reduced to the challenge of reaching more transparent and efficient markets that better allocate resources (WB, 2006, p. xii), thus 'bring[ing] people closer to markets and services' (WB, 2006, p. 175) and increasing their opportunities 'through market-oriented growth' (WB, 2006, p. 227). The neo-liberal doxa ${ }^{13}$ of the World Bank suggests that the public sector shall align its policies with the interests of the private sector to preserve economic incentives that strengthen market growth and, in the end, serve the interests of the least advantaged. Economic incentives for private investment and the promotion of PPPs in the provision of public services therefore appear as the underlying priority in policy design:

"While such equity-enhancing redistributions (of power, or access to government spending and markets) can often be efficiency-increasing, possible tradeoffs need to be assessed in the design of policy. At some point, higher tax rates to finance spending on more schools for the poorest will create so much disincentive to effort or investment (depending on how the taxes are raised), that one should stop raising them" (WB, 2006, p. 10)

The promotion of PPPs is further legitimized by its assumed capacity to go beyond the existing power relations in administrative and political circles, to cut the patron-client relations and to undermine informal or discriminatory decision-making processes and regulations. The emphasis is thus put on empowerment of the population and accountability between the population and the

${ }^{13}$ Defined by Bourdieu in 1977 as 'traditions and beliefs which exist beyond discourse or argumentation' (Kabeer 1999 p. 441) 
service provider (WB, 2008, p. vi). This focus on public participation and governance reforms at the interface between the public and the service provider annihilates the political debate on the way regulations are defined, rules set and practices embedded in the political and administrative realm (WB, 2006, pp. 10, 175), pointing, on the contrary, 'towards a consensus-based model that can be assessed neutrally on the basis of its efficiency, productivity and inclusiveness [...] within an assumedly frame of market-led efficiency' (Swyngedouw, 2013, p. 832).

As seen above, the non-notified slums cannot rely on such calls for accountability, the cluster of disadvantage they live in forcing them to vote for the patron most able to protect them. Relying on the "benevolent" (L. Mehta, 2014) character of this elected representative to undermine his own status as patron is unlikely to be considered a wise recommendation in policy-making. A similar bias towards a residualist approach is however visible in the Indian policy-making, which neglects categorical inequalities and the necessary political debates it entails.

The last Indian National Water Policy of 2012 highlights this cost-benefit analysis and accountability discourse beyond proclaimed concerns for equity (MoWR, 2012, sec. 1.2). Even though it recognizes 'basic principles [related to] equity and social justice in the use and allocation of water' (MoWR, 2012, sec. 1.3), it indeed fails to define equity or to give operational criteria to evaluate and promote equitable policies that focus on the least advantaged and ensure 'equal rights to water, regardless of ability to pay' (UNDP, 2011, p. 71). Only vague requirements for 'access to a minimum quantity of potable water for essential health and hygiene to all its citizens, available within easy reach of the household' (MoWR, 2012, sec. 3.2) are set. The policy, which never mentions the words 'right,' 'human right' or 'right to water,' fails to mention the existing inequalities in access between poor and rich neighborhoods, and the equity challenges of water supply in informal settlements - and, more specifically, in non-notified slums. The call for private participation (MoWR, 2012, sec. 12.3) is not justifying how regulating a private service provider will alter the structural causes of the existing cluster of disadvantage.

The JNNURM takes a similar stand. In the JNNURM inaugural speech, the Indian Prime Minister Manmohan Singh called for a reform that would allow the State to go beyond the 'narrow-focused project approach' and 'address the problems of law, systems and procedures reform' by enabling 'the city-level institutions to become financially strong and viable and our 
development program relating to the removal of poverty becoming increasingly bankable' (Prime Minister, 2005). However, the capacity of this infrastructure development program to effectively target 'the urban poor' is called into question, as the debate on budget allocation and the potential conflict of interest between subsidizing infrastructures for the poor and enabling 'city-level institutions to become financially strong and viable' are silenced by a win-win discourse that considers the response to the 'needs of the poor' as a prospect for economic growth, rather than as a social justice and achievement per se: 'giving the urban poor land rights at affordable rates may see an increase in private investment. This in itself will improve the quality of living in our cities' (Prime Minister, 2005).

The World Bank and the Indian government therefore broadly adopt the development discourse on well-being and equity and legitimize their action by recognizing their responsibility and contribution towards equity. However, the imperative to focus on the least advantaged is blurred by a similar imperative that these organizations pursue in ensuring the financial efficiency and economics of incentives, which is neither defined nor questioned (Parsai, 2012) and which doesn't aim to tackle categorical inequalities. The economic sphere appears to be disconnected from the political field, with an equity notion that is hindered by a prominent focus on a technical, financial and managerial language that depoliticizes infrastructure development programs (JnNURM Technical Cell, 2010, sec. 6, 22; Lakshmanan, 2008; MoUD \& MoUEPA, 2011, pp. 3-5).

\section{Politicizing equity by making international donors and MNCs accountable}

The equity discourse thus seems to be pursued as a rhetorical element (Kallio, 2007) by international donor agencies, national governments and MNCs who want to 'integrate and extend existing approaches' (WB, 2006, p. 226), instead of recognizing that 'business-as-usual is neither sustainable nor equitable' (UNDP, 2011, p. 82), and that the focus on the least advantaged requires a definition of operational thresholds that can serve as a legally binding mechanism on which the population of non-notified slums could base their claims and accountability calls. The "Protect, Respect and Remedy" framework of John Ruggie (Ruggie, 2008b) and the OECD Guidelines for Multinational Enterprises (OECD, 2011) highlight the shift in international soft law pushing firms to respect human rights and influence one's 'business relationships' towards 
effective promotion and fulfillment of the human rights framework in one's sphere of influence to avoid complicity charges (Ruggie, 2008a).

The proposals made in the 2006 World Bank Development Report insisted on the role of regulators and of accountability to enforce contractual obligations, without questioning the way equity criteria were included in contracts and the way silences in these contracts reflected stalemates and durable inequalities. PPPs thus remain entangled in a complex web of accounting and financial cost-benefits analysis, with the reference to accountability acting as a consensual term with no concrete implication of the way the JNNURM is implemented and used for triggering large-scale political reforms towards taking the least advantaged into account:

Regulators have a key role in ensuring that the public interest is being served. This includes safeguarding the value of public assets, upholding the sectoral norms relating to health and safety, providing information about the performance of the service provider, and enforcing compliance with contractual obligations. If effective, regulation will have an important impact on efficiency and equity. (WB, 2006, p. 174)

Ambiguity on what constitutes operational equity and pro-poor criteria therefore remains widespread in national development programs, as illustrated in the frame of the 'slum-free city' Rajiv Awas Yojana (RAY) scheme, which was built on a similar agenda to the JNNURM and its pro-poor segment BSUP. This ambiguity maintains the local political and administrative hold over wide sections of the society. This was revealed in Bakker's 'governance failure' concept, which highlights the biases of decision-making and institutional reforms that are not able to address 'systematic biases against the poor households,' whichever status (public or private) the service provider has and whatever 'stated pro-poor policies' are invoked (Bakker et al., 2008, p. 1894). A normative framework for minimal threshold levels and the sovereignty of local administration on budgets and resources to ensure these basic service levels are thus required if human right to water is to be achieved. The allocation of subsidies, land-use reforms and administrative incoherence have to be dealt with by a wider multi-sector approach and a political and public debate that sets operational guidelines (Gerlach \& Franceys, 2010; A. Kundu, 2013).

This requires stakeholders involved in infrastructure development to question the relevance of subsidies and institutional reforms beyond a cost-benefit rationale (Nussbaum, 2000a). The World Bank supports the JNNURM program (The Economic Times, 2009). To address the 
'economy of practices' (Bourdieu, 1984) which maintain 'durable inequalities' (Tilly, 1998), the World Bank is thus expected to impose stronger conditionalities on its aid and to be more accountable towards the public when supporting such infrastructure development programs (Ebrahim, 2009). As revealed by the Nagpur pilot project, after decades of discrimination, one shall indeed not wait for "benevolent states" and elected representatives to trigger these reforms and "re-order water rights that will have just outcomes for the poorest" (L. Mehta, 2014, p. 68). Social movements and mobilization are also expected to play a role in pushing for the inclusion of the poor (Tarrow, 2011, 2012; Tilly \& Wood, 2009).

The ongoing societal constitutionalism in international law seems to open new fields for contesting the status quo. The rise of new normative spaces made of laws, practices and discourses (Backer, 2011b; Lhuilier, 2013) empowers the worse-off to question the prevailing power relations and violations to human rights. Public and private corporate codes of conduct are thus creating a new international legal order (Ruggie, 2004). If one goes by the UN Global Compact definition of complicity of corporations in human rights abuses, one reads that complicity can be either direct, beneficial, or silent. In Nagpur's PPP project, the World Bank and the private operator might thus be asked to take a stand and pressurize the State to change its operational rules so as to avoid further discrimination of non-notified slums, based on the definition of silent complicity, which 'describes the way human rights advocates see the failure by a company to raise the question of systematic or continuous human rights violations in its interactions with the appropriate authorities' (Ruggie, 2008a, p. 18). John Ruggie thus noted that due diligence by investors and private actors was necessary to ensure that, 'whether or not there is a risk of legal liability [...] the company is not complicit, or otherwise implicated in human rights harms caused by others' (Ruggie, 2008a, p. 19). In the aftermath of the Rana Plaza collapse in Bangladesh in May 2013, trade unions have signed legally-binding agreements with multinationals and with the State in order to improve the employee's working conditions and wages in the garment industry (Foundation Bangladesh Accord, 2013). Despite acknowledged limits of this initiative, among which one might cite the free-rider problem of some multinationals in signing alternative non-binding agreements (Gunther, 2013) or in attributing responsibilities for compensating victims and affected communities (Clean Clothes Campaign, IndustriALL, 2014; Rana Plaza Arrangement, 2013), the constitutionalization of the activities of corporations sets precedents and opens new normative spaces for local social movements in 
Nagpur, in India and elsewhere to demand for stringent codes by investors and corporations (Backer, 2011a; Bottomley, 2007; Robé, 1996).

\section{CONCLUSION}

We have highlighted the missing political dimension of equity in the ongoing infrastructure development reforms. Based on the rawlsian maximin principle and the concept of disadvantage defined by Wolff and de-Shalit (2007), equity consists in identifying the least-advantaged population and promoting public policies that de-cluster disadvantage. This approach is in line with the human rights framework and the perspective adopted by international organizations such as the UNPD and the World Bank, who express the need to focus on the worse-off.

However, public service provision in today's Indian metropolis suffers from a combination of discriminative administrative processes and political mediation. Through a rational 'inverse cross-category risk' (Wolff \& De-Shalit, 2007), the population of non-notified slums rationally undermines its political autonomy to guarantee its protection and access to public services. The state's inability to formally provide basic services to the non-notified population creates and perpetuates the conditions for clientelism and uneven power relations. In this 'mediated state' which we identified and described, the non-notified population appears as the least advantaged, and equity implies a need to focus on de-clustering the disadvantage they suffer from.

While the World Bank and the Indian government have all advocated in favor of equity, they have responded to the challenge of universal access to public services by promoting private participation and PPPs. However, the JNNURM reveals that technical, financial and managerial aspects have been prioritized in the contract signed with the private service provider without tackling categorical inequalities.

A paradigm shift from a trade-off on an economic and technical basis towards a holistic vision of urban development that questions existing power relations, electoral strategies and administratively embedded discriminations will open up new debates and allow policy-makers and regulators to propose and legitimize indicators that the Indian National Water Policy broadly calls for (MoWR, 2012, sec. 3.2). 
Grounding subsequent urban infrastructure development projects on concrete equity criteria and minimal thresholds inspired by the human rights and capabilities discourse on disadvantage shall provide a new perspective to address cost-benefit dilemmas through the lenses of tragic choice (Nussbaum, 2000a). In this regard, the inchoative but fast developing international legal order promoted by the OECD Guidelines, the John Ruggie framework or the UN Global Compact might provide new resources to activists, social movements and non-governmental organizations to make investors and corporations more accountable, possibly breaking through the persisting categorical inequalities embedded in today's Indian infrastructure development policies. 


\section{REFERENCES}

Albuquerque, C. (de), \& Roaf, V. (2012). On the right track. Good practices in realising the rights to water and sanitation. Lisbon: UN Special Rapporteur on the human right to safe drinking water and sanitation.

Alliance. (no date). About the Alliance for Bangladesh Worker Safety. Alliance for Bangladesh Worker Safety. Retrieved from http://www.bangladeshworkersafety.org/about/aboutthe-alliance

Appadurai, A. (2002). Deep democracy: Urban governmentality and the Horizon of Politics. Public Culture, 14(1), 21-47.

ASCl, A. S. C. of I., \& Centre for Good Governance. (2011). JnNURM Rapid Training Programme. Governance and reforms: Revenue enhancement reforms. New Delhi: JnNURM. Retrieved from http://jnnurm.nic.in/capactiy-building.html

Backer, L. C. (2011a). Polycentric Governance in the Transnational Sphere: Private Governance, Soft Law, and the Construction of Public-Private Regulatory Networks for States and Transnational Corporations. Indiana Journal of Global Legal Studies, 17(1), 101-166.

Backer, L. C. (2011b). Private actors and public governance beyond the state: the multinational corporation, the Financial Stability Board, and the global governance order. Indiana Journal of Global Legal Studies, 18(2), 751-802.

Bakker, K., Kooy, M., Shofiani, N. E., \& Martijn, E.-J. (2008). Governance failure: rethinking the institutional dimensions of urban water supply to poor households. World Development, 36(10), 1891-1915.

Bénit-Gbaffou, C. (2011). "Up close and Personal" - how does local democracy help the poor access the State? Stories of accountability in Johannesburg. Journal of Asian and African Studies, 46(5), 453-464.

Berenschot, W. (2010). Everyday mediation: The politics of public service delivery in Gujarat, India. Development and Change, 41(5), 883-905.

Bottomley, S. (2007). The constitutional corporation. Rethinking corporate governance. Burlington: Ashgate.

Bourdieu, P. (1984). Distinction: a social critique of the judgement of taste. Cambridge: Harvard University Press.

Bracking, S. (2005). Guided miscreants: Liberalism, Myopias, and the Politics of Representation. World Development, 33(6), 1011-1024.

Briscoe, J., \& Malik, R. P. S. (2006). India's water economy. Bracing for a turbulent future. New Delhi: Oxford University Press.

Chandra, K. (2004). Elections as auctions. Presented at the Seminar 539: A mandate for change. Retrieved from http://www.indiaseminar.com/2004/539/539\%20kanchan\%20chandra.htm

Chatterjee, P. (2004). The politics of the governed. Reflections on popular politics in most of the world. New York: Columbia University Press.

Clean Clothes Campaign. (no date). Pay up! Compensation is long overdue. Improving working conditions in the global garment industry. Retrieved from http://www.cleanclothes.org/ranaplaza 
Connors, G. (2005). When utilities muddle through: pro-poor governance in Bangalore's public water sector. Environment and Urbanization, 17(1), 201-217.

Dravekar, S. (2011, June 27). 36\% population lives in 446 slums in city. 8.58 lakh people hardly have basic facilities. Times of India. Nagpur.

Ebrahim, A. (2009, September 10). The World Bank's disclosure policy review, and the role of democratic participatory processes in achieving successful development outcomes. Testimony presented at the Committee on Financial Services, U.S. House of Representatives, Washington DC.

Estache, A., \& Griffel-Tatjé, E. (2013). How (un)even was the distribution of the impacts of Mali's Water Privatisation across stakeholders? Journal of Development Studies, 49(4), 483-499.

Foundation Bangladesh Accord. (2013). Accord on Fire and BUilding Safety in Bangladesh. Geneva: Accord. Retrieved from http://www.bangladeshaccord.org/

Gerlach, E., \& Franceys, R. (2010). Regulating water services for all in developing economies. World Development, 38(9), 1229-1240.

GoM, G. of M. Maharashtra Slum Areas (Improvement, clearance and redevelopment) Act, 1971 (1971).

Gunther, M. (2013, July 11). Gap spearheads new alliance for Bangladeshi worker safety. Retrieved from http://www.theguardian.com/sustainable-business/gap-alliancebangladeshi-worker-safety

Hailu, D., Guerreiro Osorio, R., \& Tsukada, R. (2012). Privatization and renationalization: what went wrong in Bolivia's water sector? World Development, 40(12), 2564-2577.

Harriss, J. (2002). Depoliticizing development. The World Bank and social capital. London: Anthem Press.

Heller, P., \& Evans, P. (2010). Taking Tilly South: durable inequalities, democratic contestation, and citizenship in the Southern metropolis. Theoretical Sociology, 39, 433-450.

Hickey, S. (2008). The return of politics in development studies I: getting lost within the poverty agenda? Progress in Development Studies, 8(4), 349-358.

Hitavada, S. C. (2011, November 4). Private company to take over water supply on 15th. Orange City Water Supply Company yoy ake over water distribution network from NMC. Hitavada - Cityline. Nagpur.

IndustriALL, G. U. (2014, April 24). Brands' commitment to Rana Plaza compensation fund woefully inadequate. IndustriALL Global Union. Retrieved from http://www.industriallunion.org/brands-commitment-to-rana-plaza-compensation-fund-woefully-inadequate

Jenkins, R. (2005). Globalization, Corporate Social Responsibility and Poverty. International Affairs (Royal Institute of International Affairs 1944-), 81(3), 525-540.

Jha, S., Rao, V., \& Woolcock, M. (2005). Governance in the Gullies: democratic responsiveness and leadership in Delhi's slums. World Bank Policy Research Working Paper, (3694).

JnNURM Technical Cell. (2010). JnNURM - A response to india's Urban Challenges. New Delhi: Government of India.

Judge Ahluwalia, I., \& Nair, R. (2010, November 24). 24x7 water for all. Nagpur's integrated water management approach has helped it lead in providing continuous supply. The Indian Express. Nagpur. Retrieved from http://www.financialexpress.com/news/24x7water-for-all/714984/0 
Kabeer, N. (1999). Resources, agency, achievements: reflections on the measurement of women's empowerment. Development and Change, 30, 435-464.

Kallio, T. J. (2007). Taboos in Corporate Social Responsibility discourse. Journal of Business Ethics, 74(2), 165-175.

Keefer, P., \& Khemani, S. (2004). Why do the poor receive poor services? Economic and Political Weekly, 39(9), 935-943.

Kitschelt, H., \& Wilkinson, S. (2007). Patrons, clients and policies: patterns of democratic accountability and political competition. Cambridge: Cambridge University Press.

Kohli, A. (1990). Democracy and discontent: India's growing crisis of governability. Cambridge: Cambridge University Press.

Korten, D. C. (1995). When corporations rule the world. London: Earthscan.

Krishna, A. (2013). Stuck in place: investigating social mobility in 14 Bangalore slums. Journal of Development Studies, 49(7), 1010-1028.

Kundu, A. (2013). Making Indian cities Slum-free: Vision and Operationalisation. Economic and Political Weekly, 48(17), 15-18.

Kundu, D., \& Samanta, D. (2011). Redefining the inclusive urban agenda in India. Economic and Political Weekly, 46(5), 55-63.

Lakshmanan, L. (2008). Public-private partnership in Indian infrastructure development: issues and options. Reserve Bank of India Occasional Papers, 29(1), 37-77.

Leftwich, A. (1993). Governance, democracy and development in the Third World. Third World Quarterly, 14(3), 605-624.

Leftwich, A. (2005). Development studies and the rediscovery of social science. New Political Economy, 10(4), 573-607.

Lhuilier, G. (2013). Minerais de guerre. Une nouvelle théorie de la mondialisation du droit. (Working Paper No. 2013-36). Paris: Fondation Maison des sciences de l'homme.

Mann, M. (2007). Delhi's belly: on the management of water, sewage and excreta in a changing urban environment during the nineteenth century. Studies in History, 23(1), 1-30.

Mehta, L. (2014). Water and Human Development. World Development, 59, 59-69.

Mehta, M., \& Mehta, D. (2010). A glass half full? Urban development (1990s to 2010). Economic and Political Weekly, 45(28), 20-23.

MMC Consultants. (2005). Nagpur Slum redevelopment project (under JNNURM). Nagpur. Retrieved from Paper version

MoF, M. of F. (2009). Position paper on the water and sanitation sector in India. New Delhi: Government of India.

Moon, J., Crane, A., \& Matten, D. (2005). Can corporations be citizens? Corporate citizenship as a metaphor for business participation in society. Business Ethics Quarterly, 15(3), 429453.

Mosse, D. (2010). A relational approach to durable poverty, inequality and power. Journal of Development Studies, 46(7), 1156-1178.

MoUD, M. of U. D., \& MoUEPA, M. of U. E. and P. A. (2011). Jawaharlal Nehru National Urban Renewal Mission (JnNURM): Overview (p. 15). Government of India. Retrieved from www.jnnurm.nic.in

MoWR, M. of W. R. National Water Policy (2012) (2012).

NMC Commissioner. (No date). PPP in water sector: Nagpur experience. Nagpur: NMC. 
NMC, N. M. C. (2012). Water Supply system of Nagpur city. Retrieved from http://www.nagpurwater.com/PageExsiSysDetails.aspx

NMC, N. M. C., CHF, C. I., \& ESAF, E. S. A. F. (2008). Slums of Nagpur City (2008). Nagpur.

NMC, N. M. C., Nagpur Environmental Services Limited, \& OCW, O. C. W. P. L. 24x7 water supply project for Nagpur city. PPP contract agreement (2011).

Nussbaum, M. C. (2000a). The costs of tragedy: some moral limits of cost-benefit analysis. The Journal of Legal Studies, 29(S2), 1005-1036.

Nussbaum, M. C. (2000b). Women and human development. New York: Cambridge University Press.

OECD. (2011). OECD Guidelines for Multinational Enterprises. OECD Publishing.

Pangotra, P., \& Hastak, S. S. (2004). Strategy for reducing unaccounted for water in Nagpur. ASCI Hyderabad.

Parsai, G. (2012, January 21). Water policy draft favours privatisation of services. The Hindu. New Delhi. Retrieved from http://www.thehindu.com/news/national/article2820794.ece

Prime Minister, G. of I. PM launches Jawaharlal Nehru National Urban Renewal Mission (2005). Retrieved from http://jnnurm.nic.in/wp-content/uploads/2011/01/Prime-MinistersOffice.htm

Rana Plaza Arrangement. (2013, November 20). Understanding for a Practical Arrangement on Payments to the Victims of the Rana Plaza Accident and their Families and Dependents for their Losses. Rana Plaza Arrangement. Retrieved from http://www.ranaplazaarrangement.org/

Rawls, J. (1971). A theory of justice. Cambridge: Harvard University Press.

Rawls, J. (1993). Political liberalism. New York: Columbia University Press.

Rist, G. (2008). The history of development: from western origins to global faith (3rd ed.). London: Zed Books.

Robé, J.-P. (1996). Multinational Enterprises: The constitution of a Pluralistic Legal Order. In G. Teubner (Ed.), Global law without a State (pp. 45-77). Aldershot: Dartmouth.

Roy, A. (2011a, September 16). Promise of abundant water, but no shortage of doubts. Times of India - Times City. Nagpur.

Roy, A. (2011b, September 18). Billing efficiency zooms in Dharampeth zone. Times of India Times City. Nagpur.

Ruggie, J. (2004). Reconstituting the global public domain - issues, actors and practices. European Journal of International Relations, 10(4), 499-531.

Ruggie, J. Clarifying the Concepts of "Sphere of influence" and "Complicity", Pub. L. No. A/HRC/8/16 § Human rights council (2008).

Ruggie, J. "Protect, Respect and Remedy": a Framework for Business and Human Rights, Pub. L. No. A/HRC/8/5 § Human rights Council (2008).

Scherer, A. G., \& Palazzo, G. (2007). Toward a political conception of corporate responsibility: business and society seen from a Habermasian perspective. Academy of Management Review, 32(4), 1096-1120.

Sen, A. (1999). Development as freedom. New York: Oxford University Press.

Sen, A. (2004). Elements of a theory of human rights. Philosophy \& Public Affairs, 32(4), 315356. 
Sen, A., \& Dreze, J. (2002). India: Development and participation. New Delhi: Oxford University Press.

Sen, A., \& Nussbaum, M. C. (1993). The quality of life. Oxford: Clarendon Press.

Sethi, S. P. (2008). Defining the concept of good corporate citizenship in the context of globalization: a paradigm shift from corporate social responsibility to corporate social accountability. In A. G. Scherer \& G. Palazzo (Eds.), Handbook of research on global corporate citizenship (pp. 74-98). Cheltenham, UK: Edward Elgar.

Stiglitz, J. E., Sen, A., \& Fitoussi, J.-P. (2010). Mis-measuring our lives. Why GDP doesn't add up. The New Press.

Swyngedouw, E. (2004). Social power and the urbanisation of water. Flows of power. Oxford: Oxford University Press.

Swyngedouw, E. (2013). UN Water Report 2012: Depoliticizing Water. Development and Change, 44(3), 823-835.

Tan, J. (2012). The pitfalls of water privatization: failure and reform in Malaysia. World Development, 40(12), 2552-2563.

Tarrow, S. (2011). Power in movement: social movements and contentious politics (3rd ed.). Cambridge: Cambridge University Press.

Tarrow, S. (2012). Strangers at the gates: movements and states in contentious politics. Cambridge: Cambridge University Press.

The Economic Times, E. bureau. (2009, December 10). World Bank's \$1b loan for JNNURM to come with strings. The Economic Times. New Delhi.

Tilly, C. (1998). Durable inequality. Berkeley: University of California Press.

Tilly, C., \& Wood, L. J. (2009). Social movements, 1768-2008. Boulder: Paradigm Publishers.

UN ECOSOC, U. E. and S. C. Substantive issues arising in the implementation of the international covenant on economic, social and cultural rights, Pub. L. No. E/C.12/2002/11 § 3 (2003).

UN, S. G. (2006). Millenium Project: goals, targets and indicators. Retrieved from http://www.unmillenniumproject.org/goals/gti.htm

UNDP, U. N. D. P. (1990). Human Development Report 1990: Concept and Measurement of human development. New York: Oxford University Press.

UNDP, U. N. D. P. (2006). Human Development Report 2006: Beyond scarcity: power, poverty and the global water crisis. New York: Palgrave Macmillan.

UNDP, U. N. D. P. (2011). Human Development Report 2011: sustainability and equity: a better future for all. New York: Palgrave Macmillan.

UNGA, U. G. A. International Covenant on economic, social and cultural rights, Pub. L. No. Treaty Series vol. 993 (1966).

UNGA, U. G. A. Towards global partnerships, Pub. L. No. A/RES/60/215 § 59 (2006).

UNGA, U. G. A. The human right to water and sanitation, A/RES/64/292 § 48 (2010).

Walzer, M. (1983). Spheres Of Justice: A Defense Of Pluralism And Equality. New York: Basic Books.

WB, W. B. (2004). World Development Report 2004: Making services work for poor people. New York: Oxford University Press.

WB, W. B. (2006). World Development Report 2006: Equity and Development. New York: Oxford University Press. 
WB, W. B. (2008). Key topics in public water utility reform (No. 17). Water Sector Board of the Sustainable Development Network, World Bank.

WB, W. B. (2011). Public Private Partnership in Infrastructure Program (PPPI): about. Retrieved from http://go.worldbank.org/E787QINP90

Weber, M. (1968). Economy and society: an outline of interpretative sociology. New York: Bedminster Press.

WHO, \& UNICEF. (2010). Estimates for the use of improved drinking-water sources. India. Retrieved from www.wssinfo.org/fileadmin/user_upload/resources/IND_wat.pdf

Wolff, J., \& De-Shalit, A. (2007). Disadvantage (Oxford University Press.). New York: Oxford University Press.

Zerah, M.-H. (2000). Household strategies for coping with unreliable water supplies: the case of Delhi. Habitat International, 24(3), 295-307.

Zerah, M.-H. (2008). Splintering urbanism in Mumbai: contrasting trends in a multilayered society. Geoforum, 39(6), 1922-1932. 
ESSEC Business School Avenue Bernard Hirsch BP 50105

95021 Cergy-Pontoise Cedex France

Tél. +33(0)134433000

$\mathrm{Fax}+33(0) 134433001$

www.essec.fr

\section{ESSEC Executive Education} CNIT BP 230

92053 Paris-La Défense France

Têl. + $33(0) 146924900$

Fax +33 (0)1 46924990

http://formation.essec.fi

ESSEC Business School

Singapore Campus

100 Victoria Street

National Library Building \# 13-02

Singapore 188064

essecasia@essec.fr

Tél. +6568849780

Fax +6568849781

www.essec.edu

Informations

+33 (0)134433358

www.essec.fr

renouard@essec.edu

bommier@essec.edu

ISSN 1291-9616 